\title{
SUSTAINABILITY AND GREEN DEVELOPMENT IN URBAN POLICIES AND STRATEGIES
}

\author{
CSETE, M. ${ }^{1}-$ HORVÁTH, L. ${ }^{2} *$ \\ ${ }^{1}$ Budapest University of Technology and Economics, Dept. of Environmental Economics \\ 1111 Budapest, Müegyetem rkp. 3-9., Hungary \\ (phone: +36-1-463-2018; fax: +36-1-463-1149) \\ ${ }^{2}$ Corvinus University of Budapest, Adaptation to Climate Change Research Group \\ 1118 Budapest, Villányi út 29-43., Hungary \\ (phone: +36-1-482-6261; fax: +36-1-466-9273) \\ *Corresponding author \\ e-mail:levente.horvath@uni-corvinus.hu \\ (Received $18^{\text {th }}$ October 2011; accepted $20^{\text {th }}$ March 2012)
}

\begin{abstract}
Adaptation to climate change is increasingly becoming a priority for policy action. In April 2009, the European Commission released a White Paper outlining a proposed framework for action to reduce vulnerability and adapt to climate change (European Commission, 2009). The White Paper refers to the importance of a climate adaptation strategy and sustainability that integrates all areas of regional and municipal development including agriculture, forestry, fishery, energy, public infrastructure (incl. building, transport, energy and water supply), tourism, human, animal and plant health, water resources and ecosystem loss (including marine ecosystems and biodiversity). One of the main issues is how to and why integrating the green developments into urban policies. In this paper we show the main objectives of London's greening program, and some possible elements of the green developments in Csömör's adaptation strategy. Comparing the two examined cities there are differences according to their size, population, greening possibilities and financial backgrounds. However, it can be seen that the focus points of the adaptation strategies are more close to each other.
\end{abstract}

Keywords: climate change, sustainability, urban policy, green development

\section{Sustainability and urban policy}

The significance and relevance of sustainable development is not to be contested, as it is clear that the anomalies in natural cycles and the reproduction of goods endanger human existence. The term sustainable development by the definition of United Nations World Commission on Environment and Development (Brundtland Commission, 1987) is "development that meets the needs of the present without compromising the ability of future generations to meet their own needs".

Sustainable development is a global ambition and the European Union assumed significant role in fostering the practical implementation. Furthermore, sustainable development is one of the fundamental objectives of the EU, as confirmed in its Treaty as well.

In 1992, on the first Earth Summit (Rio de Janeiro), the European Community made a commitment to implement sustainable development. In 2001, the Gothenburg European Council adopted the EU Sustainable Development Strategy. This Sustainable Development Strategy was renewed in 2006. In 2007 and 2009, progress reports were published according to the EU Sustainable Development Strategy.

The EU Sustainable Development Strategy recognized that holistic approach is a basic need to enhance the realization and in the long term environmental protection, 
social cohesion and economic growth has to develop collateral. The main threats of sustainable development related to the future well-being of European society were defined in the Gothenburg EU Sustainable Development Strategy:

- Possible effects of climate change;

- Severe threats related to public health, food safety;

- Poverty and social exclusion;

- Ageing of the population;

- Loss of biodiversity;

- Eroding agricultural land;

- Increasing waste volume;

- Transport related problems.

In relation to the issue of climate change it is worth mentioning that from the viewpoint of the both term sustainability and climate change a holistic approach is needed to be able to examine the interactions, moreover to find the possible solutions. According to the statement of the IPCC Report climate change can be one of the biggest dangers, risk of sustainable development. Nevertheless, the third report of IPCC emphasized in relation to sustainability that it can be an advantage in the mitigation of climate change (IPCC, 2001; IPCC, 2007). In 2006, the Renewed EU Sustainable Strategy identified 7 key challenges:

1. Climate change and clean energy;

2. Sustainable transport;

3. Sustainable production and consumption;

4. Better management of natural resources;

5. Public health threats;

6. Social inclusion, demography and migration;

7. Fighting global poverty.

Sustainability - which is a way of thinking, life, production and consumption covers all dimensions of human existence, its relation to natural resources, the economy and society. Sustainability can be the solution - beside research and development processes - to global problems like globalising economy and market competition, global warming, poverty and famine. The actions of the United Nations from Rio to Johannesburg and EU decisions seem to underpin this.

It seems to become evident from previous experiences that among the levels of sustainability (global, regional and local) the local level is where the implementation of sustainability can be actually highlighted, in accordance with the interests of local communities (Csete, 2009). On local level, especially in the cities, urban policy and planning has significant role in case of each key challenges that were defined in the Renewed EU Sustainable Development Strategy (2006).

Sustainable urban development has been firstly highlighted in the social research (Banister and Button, 1993; Owens, 1992; Rickaby, 1991). It has been continued by an increasing awareness in Europe and in other parts of the world. Recently, the European ministers responsible for urban policy and spatial development also have been realized the importance of sustainable development related issues. In 2007, the Leipzig Charter on Sustainable Cities and the Territorial Agenda of the European Union highlighted the role of local strategies, urban policy and planning tools in order sustainable urban 
development. Furthermore, joint objectives were identified and possible solutions were evaluated.

The adoption of the Leipzig Charter shows the growing importance of urban areas in social, cultural and economic issues. On the other hand, it is pivotal to underpin the emissions of urban lifestyle and the possible green developments in order to decrease the negative externalities. The central message of the Charter is the importance of "integrated strategies" and "coordinated actions". In favour of this message a reviewed institutional background is needed. The sustainable, healthy and environmental friendly cities are important for all levels of governments (local, regional, national).

In addition to this, the Leipzig Charter focuses on two key objectives. Firstly, an integrated urban development should be applied in Europe. Secondly, the especially disadvantaged urban neighbourhoods have to become an important part of the integrated urban development policy. The Charter identified 5 main problems on which urban policy should concentrate:

1. Dealing with deprived neighbourhoods;

2. Improving the public spaces;

3. Modernising infrastructure with a focus on saving energy;

4. Better education for young children and refresher training for workers;

5. Better and more efficient public transport in and between cities.

The Leipzig Charter can underpin the increasing role of green developments focusing urban policy tools related to energy efficiency, energy saving, sustainable mobility, development of green areas and the take into consideration their environmental services as well. All of these factors play pivotal role in the urban quality of life as well (Nijkamp and Perrels, 2009).

In 2008, the Marseille Statement also reconfirmed the main focus points of the Leipzig Charter and in addition draws special attention to the importance of the possible impacts of climate change on urban territories. Besides a practical toolkit development has been also decided toward the better understanding of common sustainability goals. The basic concept was the forming of a common European Reference Framework for Sustainable Cities.

In summary, it can be stated that sustainable cities have increasing importance according to global environmental phenomena and living circumstances. Sustainable cities are cities where socio-economic interests are brought together in harmony with environmental and energy concerns in order to ensure continuity to change (Nijkamp and Perrels, 2009).

\section{The “Green" in urban policy}

Nowadays facing the ecological and climate related problems in urban policies, is one of the biggest issues of municipalities. Most cities are met with similar environmental problems, such as high levels of traffic and congestion, greenhouse gas emissions, poor air quality, high noise level, urban sprawl, poor quality built environment and the treatment of wastewater and waste. The increasing resource utilization of the urban inhabitants plays a significant role in these negative externalities caused mostly by the changes in urban lifestyle. Furthermore, these problems are strictly related to poverty and socio-economic conditions as well. 
It can be stated that climate change is a growing problem for urban areas. Actions on local level are important both in adaptation (protection against the possible effects) and in mitigation (decreasing or slowing down the effects of climate change). Climate change can have direct impact on urban areas caused by extreme weather conditions, floods, droughts, soil damage and erosion etc. Cities are peculiarly vulnerable to the possible effects of climate change and the inhabitants need to be protected from risks related to their health or well-being. The mitigation or adaptation actions can lead to the reduction of cities environmental performance. The new urban policy tools and solutions may resulted in new economic opportunities and investments through cleaner technologies, eco-innovations etc. Thus cities also can have major role in fostering environmentally friendly industries, technologies, products and last but not least sustainable lifestyle. The green surface proportion of settlements also plays significant role especially related to city-climate effects (Bakay, 2012).

More than half of the world population living in urban areas, thus the sensitivity and the vulnerability is higher than at the countryside. For instance, currently over $70 \%$ of EU citizens live in urban areas and most of the EU's population live in medium-sized (over 50000 inhabitants) cities (EC DG for Regional Policy, 2009). According to this, $25 \%$ of the US population lives in metropolises (over five million inhabitants) against the $7 \%$ in the EU-27. There is no doubt that cities have increasing importance in regional development.

Realising the above mentioned problems the main task in urban policies is how to build the "green" into the adaptation strategies. The significant consequences of green developments are:

- Keeping and increasing the green spaces;

- Care about the urban ecosystems and stop the biodiversity loss;

- Rule and ease the urban microclimate;

- Improve human health, the quality of living;

- Increasing adaptation;

- Blunt the effects of harmful meteorological events.

Green areas can help to regulate floodwater, mitigate urban heat, improve air quality and provide space for sustainable social activities. The related environmental services and those economic, social and environmental benefits have increasing importance in sustainable and climate friendly urban development (Westphal, 2003). Not only the green areas however the related positive externalities are threatened by heat stress and flooding (worse by climate change) but also by urban sprawl and development; they are the same time becoming more valuable and more threatened. For instance, special examinations were focusing on the green surfaces of the housing estate in Budapest. The main aim of this research was to elucidate how these green areas can influence the urban ecological system of a city (Bakay, 2012) and due to the results the open spaceand green-system planning can be developed in accordance with mitigation and adaptation efforts.

In case of initiating urban climate policies and strategies, the developers should follow some simple, but very important key rules. There is no doubt that cities are dynamic and complex systems. Climate change will interact with existing urban problems: some problems will get worse, some new problems will emerge. Vulnerability to climate change is definitely concentrated in cities, and urban climate change adaptation strategies need to be developed to integrate with - and build on - 
existing sectoral and cross-sectoral agendas at the city level. However, old solutions will not solve new problems. Urban adaptation requires innovation, learning and new governance structures. Complexity and uncertainty present real barriers to decisionmakers on the ground, particularly give the complex interaction of vulnerabilities at the city level. No single type of measure is able to eliminate vulnerability to climate change, a portfolio approach, for example combining institutional, technological and infrastructure responses, is likely to be the most effective.

In the frame of the GreenKeys project a Guide For Urban Green Quality (Costa et al., 2008) was developed in order to foster new urban green policies. The GreenKeys project was part-financed by European Union Community Initiative INTERREG III B CADSES and the German Federal Ministry of Transport, Building and Urban Affairs. The GreenKeys Guide is focusing on problem solving and containing methods, tools and the available case studies and best practices in the 12 cities of 7 countries. It describes the approach for formulating Urban Green Space Strategies and gives useful recommendations for the management of urban green spaces.

Adaptation to climate change occurs through adjustments in human and natural systems to decrease vulnerability in response to observed or expected changes in climate and associated extreme weather events (SEC, 2007). It involves changes in perceptions of climate risk and in social and environmental processes, practices and functions to reduce potential damages or to take advantage of new opportunities. Adaptation is a cross-sectoral, multi-scale and trans-boundary issue, which requires comprehensive and integrated modelling methodologies (Uhel and Isoard, 2008) in urban planning as well.

Mitigation and adaptation are closely related and should be considered together rather than separately (Csete and Szendrö, 2011). Fostering local sustainability can also play an important role both in adaptation and mitigation strategies according to the precautionary principle causing several positive externalities and synergic effects (Biesborek et al., 2009). Urban green spaces are important in adaptation, however they also have role in mitigation as well. All kind of urban green areas contribute to the adaptation of cities to the possible effects related to climate change. Furthermore, open spaces within cities support adaptation more efficiently compared to greenbelts. According to mitigation due to green spaces the plants clean the air, reduce $\mathrm{CO}_{2}$ level, their cooling effect decrease the demand for energy-intensive appliances, e.g. airconditioning (Ministry of Interior, Hungary - VÁTI, 2011).

Different modes of local governance can be applied by the municipalities, regardless of the settlement size, in order to strengthen mitigation and adaptation activities (Bulkeley and Kern, 2006) These main types of governing climate change are usually utilized in parallel on local level: self governing, provisions, regulations, enabling and partnership (Bulkeley et al., 2009). All five local governing types can underpin urban greening programs. Self-governing is mainly focusing on the activities and organizations of the municipalities mainly focusing on mitigation. Provisions are related to the services or the municipality, such as the ability to ensure climate-friendly transportation, energy consultancy or direct financial support that can help to improve green areas as well. Regulation is usually focusing on the implementation of national laws and different kinds of regulations related to climate change. Occasionally the local regulation can be stronger than the national one that can be useful for the green areas related environmental services and those socio-economic benefits as well. Enabling means the ability to motivate different settlement stakeholder groups in order to foster 
the practical implementation of mitigation and adaptation actions. The motivation usually means providing useful information. Partnership can help to manage local climate actions between different non-state and state stakeholders.

There are settlements on different levels with divergent characteristics (e.g. amount of local incomes, level of GHG emission, share of green surfaces, possible effects related to climate change, vulnerability, number of residents etc.) that can basically influence the possible urban greening management tools. The aim of the case studies is highlighting urban greening programs and activities as part of urban adaptation strategies. This article is focusing on two special settlement types in Europe. One of them is a well-known megacity that has over 10 million inhabitants. Despite the huge number of stakeholders the city has leading role in climate change related urban activities that can give good examples for other cities as well. The other example is a Hungarian city located in the suburban region, in the commuter belt of Budapest. The examinations highlight the possible adaptation tools and urban policy developments in this settlement to be able reinforce the urban greening activities in the settlement.

\section{Urban greening programs, a case study: London}

London was one of the first cities that established an urban greening program as a part of its adaptation strategy. Developing urban greening programs is one of the best solutions to fight against climate change and to foster the practical implementation of more sustainable and resilient cities. Urban greening offers improvements in air, water, and land resources by absorbing air pollutants, increasing water catchment and floodplain surfaces, and stabilizing soils. Urban forests act as temperature buffers providing shade in the summer, and wind break in the winter in addition to reducing noise pollution and $\mathrm{CO}_{2}$ levels, and providing a habitat for wildlife. Lastly, the overall benefits to society, particularly to low-income residents, are significant. They include the contribution of trees and vegetation to the mental and physical health of the populace, and the provision of recreational opportunities and an outdoor classroom for environmental education. In addition, they provide aesthetic improvements to an environment otherwise dominated by asphalt and concrete.

\section{Effectiveness of greening}

One of the key objectives of the urban greening programs is to reduce the risk and sensitivity of people, property and nature to the urban heat island effect and surface water flooding.

The measure aims to address the adaptation challenges of river floods, intense precipitation, drainage and flash flooding, heat waves and urban heat island effect, increased health and disease and biodiversity loss. An urban greening programme has standalone benefits, so even if climate scenarios and socio-economic scenarios change, increased green space will still be effective.

\section{Side effects}

The urban greening programs have numerous side benefits including conservation of biodiversity and improving air quality, which enhance quality of life at the neighbourhood level. Also has the potential to improve public health and some elements of the programme are designed to meet social objectives, such as reducing current areas 
of deficiency for access to nature. In particular, street tree planting has been prioritised according to the coincidence of areas with lowest street tree density; areas of multiple deprivation; poor air and noise quality; and, areas of deficiency for access to nature.

\section{Climate change mitigation}

Extensive tree planting can make a small contribution to carbon sequestration; also possibility for use of trees as carbon neutral fuel source for combined heat and power etc. Green roofs can provide additional insulation, thereby reducing energy usage.

\section{Environmental objectives, conservation of biological diversity}

Habitat creation can be through woodland creation and improvement/linking of existing green space. Increasing vegetation cover (especially trees) can help improving air quality. A climate change adaptation driven programme could have adverse impacts by encouraging creation of low grade habitat (e.g. secondary woodland) on existing high quality habitat (e.g. flower-rich grassland). Increasing tree cover can increase the pressure for water resources, especially in warm summers. However, this risk is somewhat mitigated by choosing the right tree species and the right locations, with the projected impacts of climate change in mind.

\section{Economic objectives}

Increased green cover can have important economic benefits for both residents and businesses in terms of increased property value and desirability. Green roofs can increase the lifetime of a flat roof membrane, reducing the frequency at which roofs need to be replaced. Green infrastructure as a whole also acts to attenuate rainfall, reducing the total volume of water that enters sewers (and thus requiring treatment) and can reduce the adverse economic impacts of surface water flooding. Beside the environmental objectives, the climate security is a very important issue. Planting of street trees has been overseen by expert bodies in order to reduce the risk of trees causing damage to buildings.

\section{Quality of life/social objectives}

The programs have the potential to improve public health and some elements of the programs are designed to meet social objectives, such as reducing current areas of deficiency for access to nature. In particular, street tree planting has been prioritised according to the coincidence of areas with lowest street tree density; areas of multiple deprivation; poor air and noise quality; and, areas of deficiency for access to nature.

\section{Adaptation strategy and urban policy at Csömör}

Csömör is located in the Region of Central Hungary. It is a suburban town near to Budapest, basically a sleeping city with approximately 9000 residents. In 2011 the Municipality of Csömör decided to develop an adaptation strategy. Our examinations related to Csömör are focusing not only on a climate change strategy, but to cover the existing other related development programs and local strategies. Behind the decisions some practical reason stands. It is very clear, that the new developed strategy should cover all the existing programs, from the urban greening programs, the environmental programs and the urban development programs as well. Because it only can work if everything is under the adaptation strategy in order to foster the practical implementation of local sustainability. 
As Csömör has a big area around the town, and most of the area are industrial parks. The other usable area's ownership structure is very divers. Thus the biggest challenge is, how and where to develop new green areas.

\section{Recommendations, possible developments}

\section{Horse stables}

After the financial crisis Csömör faces new challenges. The municipalities can't continue the inner city greenings, like urban forestry, developing public parks. They should develop a new strategy related to greening which could be self-supporting and could satisfy the needs of greening program, mitigation needs, and beside that it could create new jobs in the town. The town is the first in the world in the numbers of horse stable/capita. It is now obvious, that the town should open into this direction. It is important to be able to produce enough hay or food for horses. This is not the best solution, but could satisfy most of the needs.

\section{Energy cooperation}

To other unbalanced fact is, that near to Csömör there is a big factory is located that needs energy. The company decided to change to use renewable energy, mostly biomass. The other development trend could be the reforestation on the surrounding area, and to produce energy wood. In the co-working, the town could provide enough wood to factory. Beside the mitigation, it could be used as a recreational forest, which is very common in that area.

\section{Involve the residents}

In the town the residents are living in family houses, and of course they care about their small environment. The municipality do everything to help them, but there are no clear directions, how to help them. In these years, when the residents are in difficult financial situation, the solution could be to help them to learn the urban gardening. On one way they will care about their gardens, the produced vegetables or orchard could be higher quality, and they can involve into the greening the mostly private, but unused areas. Re-entering the "Tiszta udvar, rendes ház" (Clean yard, clean house) certificate could generate a competition between the residents.

The possible developments can be useful for local decision-making support especially in case of climate action. According to our recommendations it needs to be emphasized that four main modes of adaptation can be defined: passive, direct, indirect and non-climate-friendly adaptation (Csete and Szendrö, 2011). Green area related developments mainly belong to indirect adaptation tools e.g. urban planning tools in order to decrease urban heat island effect, shelterbelt development, open spaces, rainwater storage, irrigation etc.

From the above mentioned recommendations, it is clear that the municipality has a lot opportunity in urban greening. But for support these suggestions, they need to develop a new integrated strategy and examine the possible solution and all the additional benefits, which could lead Csömör and its resident to live in a sustainable, green and not vulnerable way. However, based on our on-site interviews it can be stated that the practical implementation can be endangered mainly, regardless from the financial uncertainties, by the lack of awareness and environmental or climate consciousness of local inhabitants. 


\section{Summary}

The role and importance of urban green spaces was highlighted in the present paper. Developing urban greening programs is one of the best solutions to fight against climate change and make sustainable and resilient cities. Furthermore, the improvement of urban green spaces can be a pivotal step towards more sustainable cities. To be able to enhance the positive externalities of urban green areas it is crucial to analyse the current state of the green spaces of the examined city. The physical, functional, ecological and economic aspects of green spaces need to be evaluated and monitored. Physical aspects can be qualitative (e.g. site structure and condition, historic and cultural values etc.) or quantitative (e.g. average of the city territory, $\mathrm{m}^{2}$ of urban green space per inhabitant, grassland and water areas etc.). Functional aspect is linked to accessibility; the ecological aspect is mainly focusing on the ecological values, biodiversity, environmental issues influencing human wellbeing etc. Finally, the economic aspect is focusing on the costs of the maintenance and the planned developments. Moreover it can give an outline related to the financing background that is crucial for the practical implementation of urban greening projects. The identification of local needs and demands, the involvement of local stakeholders also play significant role in urban green spaces development. It is fundamental to define strategic issues and priorities in order to develop an effective urban green space management plan fostering the liveability of cities. Summing up, it can be stated that urban greening plays significant role in enhancing the quality of life. This pivotal role can be encouraged by careful thought and planning regarding the countless potential socio-economic and environmental benefits due to urban and community greening programs. Through enhanced experiences of green landscapes and programs fostering active involvement in greening, green urban policies and strategies can be a very real part of the solution.

Acknowledgements. This work is connected to the scientific program of the "Development of qualityoriented and harmonized $\mathrm{R}+\mathrm{D}+\mathrm{I}$ strategy and functional model at BME" project. This project is supported by the New Széchenyi Plan (Project ID: TÁMOP-4.2.1/B-09/1/KMR-2010-0005).

\section{REFERENCES}

[1] Bakay, E. (2012): The role of housing estates' green surfaces in forming the city climate of Budapest. - Applied Ecology and Environmental Research 10(1): 1-16.

[2] Banister, D., Button, D. (eds) (1993): Transport, the environment and sustainable development. - E\&F Spon, London

[3] Biesbroek, G.R., Swart, R.J., Wim van der Knaap, G.M. (2009): The mitigationadaptation dichotomy and the role of spatial planning. - Habitat International 33: 230-237.

[4] Brundtland Commission (1987): Our Common Future - Oxford University Press, Oxford

[5] Bulkeley, H., Kern, K. (2006): Local government and the governing of climate change in Germany and the UK. - Urban Studies 43: 2237-2259.

[6] Bulkeley, H., Schroeder, H., Janda, K., Zhao, J. Armstrong, A., Chu S.Y., Ghosh, S. (2009): Cities and climate change: The role of institutions, governance and urban planning. - Fifth Urban Research Symposium 2009: Cities and Climate Change: Responding to an Urgent Agenda, France.

[7] Commission of the European Communities (2001): A Sustainable Europe for a Better World: A European Union Strategy for Sustainable Development (Commission proposal to the Gothenburg European Council). - Brussels, 15.5.2001 [COM(2001) 264 final] 
[8] Commission of the European Communities (2001): Communication from the Commission to the European Parliament, the Council, the European Economic and Social Committee and the Committee of the Regions - Mainstreaming sustainable development into EU policies: 2009 Review of the European Union Strategy for Sustainable Development. - Brussels, 24.7.2009 [COM(2009) 400 final]

[9] Costa, C.S., Graham, A., Kasperidus, H. (eds.) (2008): Green Keys @ Your City. A Guide to Urban Green Quality. - IOEER Leibniz, Institute of Ecological Regional Development, Dresden.

[10] Council of the European Union, Renewed EU Sustainable Development Strategy as adopted by the European Council on 15/16 June 2006, Brussels, 26 June 2006, 10917/06.

[11] Csete, M. (2009): The micro-regional analysis of sustainability. - PhD dissertation, Budapest University of Technology and Economics, Budapest.

[12] Csete, M., Szendrö, G. (2011): Assessment of climate policy and sustainability in Hungary. - World Academy of Science, Engineering and Technology 59: 1592-1597.

[13] Ecologic Institute, Berlin/Vienna, ICLEI, REC (2010): Adaptation to Climate Change: Policy instruments for adaptation to climate change in big European cities and metropolitan areas.

[14] European Commission, Directorate-General for Regional Policy (2009): Promoting Sustainable Urban Development in Europe. Achievements and Opportunities. - Available at: http://ec.europa.eu/regional_policy

[15] Federal Ministry of Transport, Building and Urban Affairs(ed) (2007): Leipzig Charter on Sustainable European Cities - Agreed on the occasion of the Informal Ministerial Meeting on Urban Development and Territorial Cohesion in Leipzig on 24/25 May 2007.

[16] Final Declaration of the Ministers in charge of Urban Development, agreed at the Meeting on 'Sustainable and Cohesive Cities' in Marseille on 25 November 2008.

[17] Good Practices for Urban Greening, Environment Division of the Social Programs and Sustainable Development Department of the Inter-American Development Bank 1996

[18] IPCC (2001): Third Assessment Report (IPCC TAR) - Available at: http://www.ipcc.ch/

[19] IPCC (2007): Fourth Assessment Report (IPCC AR4) -Available at: http://www.ipcc.ch/

[20] Ministry of Interior, Hungary - VÁTI (2011): Climate-Friendly Cities - A Handbook on the Tasks and Possibilities of European Cities in Relation to Climate Change. - Ministry of Interior, Hungary - VÁTI, Budapest

[21] Nijkamp, P., Perrels, A. (2009): Sustainable Cities in Europe. - Earthscan, LondonSterling, VA.

[22] Owens, S.E. (1992): Land-Use Planning for Energy Efficiency. - Applied Energy 43: 81114.

[23] Rickaby, P.A. (1991): Energy and Urban Development in an Archetypical English Town. - Environment and Planning B. 18: 153-176.

[24] SEC (2007): Green Paper from the Commission to the Council, the European Parliament, the European Economic and Social Committee and the Committee of the Regions Adapting to Climate Change in Europe - options for EU action.

[25] Territorial Agenda of the EU (2007): Towards a more competitive and sustainable Europe of diverse regions. - Agreed on the occasion of the Informal Ministerial Meeting on Urban Development and Territorial Cohesion in Leipzig on 24/25 May 2007.

[26] Uhel, R., Isoard, S. (2008): Regional adaptation to climate change: a European spatial planning challenge. - Inforegio panorama. Regional policy, sustainable development and climate change. No 25.

[27] Westphal, L.M (2003): Urban greening and social benefits: A study of empowerment outcomes. - Journal of Arboriculture 29(3): 137-147. 